\title{
ATIK BETONLARIN GERI DÖNÜŞÜMÜNDE SÜPER AKIŞKANLAŞTIRICI KATKI KULLANIMI
}

\author{
İsmail KILIÇ ${ }^{1}$
}

Özet

Çalışmada, süper akışkanlaştırııı katkının atık beton agregasından elde edilen betonların özelliklerine etkileri deneysel olarak araştırılmıştır. Atık beton agregası gerekli granülometrik değerlere sahip olmadığından dolayı, doğal agregayla uygun granülometriyi sağlayacak şekilde karıştırılmıştır. Karışım agregasından elde edilen betonun dayanımını arttırmak amacıyla süper akışkanlaştırıcı katkı karışımda \% $0.10,0.15,0.20,0.25$ ve 0.30 oranlarında kullanılmıştır. Deneysel çalışmada, elek analizi, taze beton birim hacim ağılık, taze beton kıvamı, ultrases geçiş hızı ve basınç dayanımı deneyleri yapılmıştır. Karışımdaki su miktarını azaltmak amacıyla yüksek oranda su azaltıcı özelliği olan süper akışkanlaştırıcı kimyasal beton katkısı kullanılmıştır. Süper akışkanlaştırcı katkının karışımdaki su gereksinimini azaltması nedeniyle, su-çimento oranının azalması basınç dayanımının yükselmesine neden olmuştur.

Anahtar Kelimeler: Beton, Atık beton, Geri dönüşüm, Süper akışkanlaştırıcı

\section{USE OF SUPER PLASTICIZER ADMIXTURE IN THE RECYCLED WASTE CONCRETES}

\begin{abstract}
This study, it has been investigated experimentally that effects of super plasticizer on properties of concretes to get from waste concrete aggregate. It is because that the waste concrete aggregate hasn't got proper grading curve, it was mixed with natural aggregate to supply suitable grading. The süper plasticizer were added to concrete with the rations $0.10,0.15,0.20,0.25$ and $0.30 \%$. In the experimental study, experiments of sieve analysis, unit weight of fresh concrete, fresh concrete consistance, ultrasonic pulse velocity and compressive strenght were done. A super plasticizer and high-range water reducing chemical admixture was used in the mixture. The super plasticizer was increased the values of compressive strenght.
\end{abstract}

Keywords: Concrete, Waste concrete, Recycle, Super plasticizer

\footnotetext{
${ }^{1}$ Yrd.Doç.Dr., Kırklareli Üniversitesi Mühendislik Fakültesi, ismail.kilic@klu.edu.tr
} 


\section{Giriş}

Betonun birçok önemli özelliği, betonun üretiminde kullanılan agreganın karakteristiklerine geniş ölçüde bağlı bulunmaktadır. Diğer bir deyişle beton özelliklerinin istenilen değerleri alabilmesi bu malzemenin üretiminde kullanılan agrega karakteristiklerinin bazı şartları yerine getirmesi ile mümkün olmaktadır (Özsöylev, 1993).

Dusseldorf (Almanya) inşaat atıkları geri kazanma tesisinde, inert madde ağırlıklı karışımlar (inşaat atıkları, beton atıkları, asfalt atıkları, taş-tuğla atıkları) işlenmekte ve tekrar inşaatlarda ve diğer alanlarda kullanılmaktadır (Erdin, 2004). Geri dönüştürülmüş betonun özelliklerinin daha iyi olması için geri dönüştürülmüş agrega içerisindeki 0-2 mm inceliğindeki kısmın doğal kum ile değiştirilmesi gerekmektedir (Ajdukiewicz ve Kliszczewicz, 2002). Hansen ve Narud (1983), yaptıkları deneysel çalışmalarda eski beton kırığı agregaların, doğal agregalara benzer test sonuçları verdiklerini belirlemişledir. Kırma sırasında eski beton kırıklarını, ince ve iri olmak üzere iki kısma ayırmışlardır. İri kısımları beton için kaba agrega olarak kullanmışlar, ince kısımları ise genellikle o boyutta kum kullanıldığından beton karışımında kullanmamışlardır.

Araştırmacılar tarafından eski beton kırığı agregalı betonlar üzerinde yapılan basınç dayanımı deneyleri sonucunda karışımdaki eski beton kırı̆̆ı oranının artmasıyla beton basınç dayanımının azaldığı belirlenmiştir. Özellikle taşıyıcı nitelikteki betonlarda eski beton kırı̆̆ı agregasının karışım içerisinde yüksek oranlarda kullanılmaması gerektiği belirtilmiştir (Günçan, 1995). Atık beton agregası ile üretilen betonların basınç dayanımlarının normal betona kıyasla \%20 veya bazen daha fazla oranda düşme gösterdiği belirlenmiştir (Nixon, 1978). Eğer kullanılan atık agreganın elde edildiği beton kaliteli ve su-çimento oranı iyi ayarlanmış ise doğal agregalarla üretilen betonların basınç dayanım değerlerine ulaşmak hatta o değerleri de aşmak mümkün olabilmektedir (Hansen ve Narud, 1983). Topçu (1997)'ye göre yüksek dayanımlı beton üretimi için atık beton agregası kullanılacağı zaman, özellikle atık beton agregasının su emme kapasitesini ve yaklaşık dayanımını bilmek gerekmektedir.

Mukai (1979), eski beton agregaları ile ürettiği betonların taze birim ağırlıklarını normal betonun \%8595 'i kadar ve $2020-2210 \mathrm{~kg} / \mathrm{m}^{3}$ değerleri arasında olduğunu belirtmiştir. Bu betonların hava içeriklerinin ise normal betonunkinden daha yüksek olduğunu bildirmiştir. Hansen ve Narud (1983) ise eski beton agregaları ile ürettikleri betonların hava içeriğini normal betonunkinden \%0.6 daha fazla ve bu betonların taze birim ağırlıklarının ise $2200-2250 \mathrm{~kg} / \mathrm{m}^{3}$ arasında değiştiğini belirtmişlerdir.

İşlenebilirlik taze betonda aranan en önemli özellik olarak bilinmektedir. Betoniyerden çıkan taze betonun taşınma ve kalıba yerleştirilmesi sırasında homojenliğini kaybetmemesi, kalıplar içinde kolaylıkla yayılarak ve mümkün olduğu kadar az boşluk bırakarak doldurma özelliklerinin hepsine birden betonun işlenebilme özelliği denilmektedir. Taze betonun kıvamı, yalnız ilave edilen su miktarının fonksiyonu olarak değil aynı zamanda belirli bir kıvamın elde edilmesi için su ihtiyacını tayin eden agreganın tane şekli ve granülometrisinin de bir fonksiyonudur (Postacıoğlu, 1975). Topçu ve Şengel (2004) yaptıkları çalışma sonucunda, beton üretiminde atık beton agregası kullanımının işlenebilirlik sorununu arttırdığını, özellikle \% 50'den daha fazla oranda atık beton agregası kullanılması durumunda işlenebilirlik sorununun daha da arttığını belirlemişlerdir.

Buck (1973), eski beton kırıklarının yeniden kullanılarak değerlendirilmesi ile ilgili çalışmalarında eski beton kırığı agregaların daha yüksek su emmeye sahip olduklarını belirlemiştir. Günçan (1995)'in taze betonlar üzerinde yaptığı çökme deneyleri, beton karışımında eski beton kırığı agrega oranının artmasıyla çökmenin azaldığını göstermiştir. Aynı su/çimento oranlarına sahip karışımlar için normal betonda 100 mm olarak ölçtüğü çökme değerini \%100 eski beton kırığı agregalı beton için 75 mm düzeyinde ölçmüştür.

Mukai vd. (1978), atık beton kaba agregası ve doğal kum kullanarak yaptıkları beton deneylerinin sonucunda, böyle karışımlarda aynı çökme değerlerini yakalayabilmek için yaklaşık $10 \mathrm{l} / \mathrm{m}^{3}$ veya \%5 daha fazla su kullanılması gerektiğini belirlemişlerdir. Bundan başka eğer karışım hem kaba hem de ince atık beton agregası içermekteyse bu değerlerin $25 \mathrm{I} / \mathrm{m}^{3}$ veya \%15 olması gerektiğini tespit etmişlerdir.

\section{Yöntem}

Bu araştırmada, materyal olarak imar nedeniyle yıkılan bir binadan alınan atıklar, temizlendikten sonra kırılarak atık beton agregası (R) olarak kullanılmıştır. Normal agrega olarak, doğal agrega (N) kullanılmıştır. Şahit beton üretiminde ise atık beton agregası ile doğal agreganın belirli bir oranda karıştırılmasıyla elde edilen karışım agregası (NR) kullanılmıştır. Beton yapımında bağlayıcı malzeme olarak portland çimentosu (CEM I 42.5) ve doğal kaynak suyu kullanılmıştır. Kimyasal katkı maddesi olarak ise Sikament FF adlı süper akışkanlaştırıcı ve yüksek oranda su azaltıcı özellik gösteren katkı maddesi kullanılmıştır. 
Temizlenen atık beton parçaları, konkasörde 4-8 mm ve 8-16 mm aralığındaki büyüklüklerde kırılmıştır. 4-8 $\mathrm{mm}$ ve 8-16 $\mathrm{mm}$ iki ayrı grupta kırılan atık beton agregaları su ile yıkanarak, ince toz zerreciklerinden ve küçük ahşap parçacıklarından ayrıştırılmıştır.

Elde edilen atık beton agregası, belirli elek aralıklarında kırılması sonucu beton üretiminde tek başına kullanılabilmesi için gerekli granülometrik yapıya sahip olmadığından, doğal agrega ile karıştırılarak uygun bir granülometri elde edilmiş ve bu şekilde beton üretiminde kullanılmıştır. Karışım; 0-4 mm, 4-16 mm ve 16-32 $\mathrm{mm}$ gibi üç gruba ayrılan doğal agregada, 4-16 mm doğal agrega yerine aynı aralıktaki atık beton agregasının kullanılmasıyla sağlanmıştır.

Söz konusu materyaller ile aşağıdaki beton örnekleri hazırlanmıştır ve aşağıdaki gibi simgelenmiştir.

- NRC: Doğal ve atık beton agregasının karışımından elde edilen şahit beton örnekleri

- SAC: Katkı olarak, süper akışkanlaştıııcının farklı oranlarda (\% 0.10, 0.15, 0.20, 0.25, 0.30) doğal ve atık beton agregası karışımına katılmasıyla elde edilen beton örnekleri

Beton örnekleri bir kenarı 15 cm'lik küp numunelerde 300 dozlu olarak üretilmiş ve betonlara ait karışım oranları ile ilgili malzeme miktarları Tablo 1'de verilmiştir. Beton karışım hesabı, atık beton ve doğal agreganın karışımından (NR) elde edilen beton türü için TS 802 (1985)'ye uygun şekilde yapılmıştır. Karışım hesabı yapılırken atık beton agregasının su emme ihtiyacı dikkate alınmıştır. Su/çimento oranı \%62 olarak belirlenmiştir. Süper akışkanlaştırıcı kullanılan betonların karışım hesabı yapılırken, akışkanlaştırıcının su gereksinimini azalttığı dikkate alınarak su miktarında azaltma yapılmış ve $\mathrm{S} / C ̧$ oranı $\% 48$ olarak belirlenmiştir. Tüm beton türlerinde agrega miktarları hesaplanırken, 0-4 mm, 4-16 mm ve 16-32 mm aralıklarında hesaplamalar yapılmıştır.

Tablo 1: Kullanılan beton örneklerine ait karışım miktarları $\left(1 \mathrm{~m}^{3}\right)$.

\begin{tabular}{|c|c|c|c|c|c|c|c|c|}
\hline \multirow{2}{*}{$\begin{array}{l}\text { Karışım } \\
\text { Kodu }\end{array}$} & \multirow{2}{*}{\multicolumn{3}{|c|}{$\begin{array}{c}\text { S-Ç } \\
\text { Oranı } \\
(\%)\end{array}$}} & \multirow{2}{*}{$\begin{array}{c}\text { Çimento } \\
\text { (kg) }\end{array}$} & \multirow{2}{*}{$\begin{array}{l}\mathrm{Su} \\
(\mathrm{kg})\end{array}$} & \multirow{2}{*}{$\begin{array}{c}\text { Doğal } \\
\text { (0-4) } \\
\text { (kg) }\end{array}$} & \multirow{2}{*}{$\begin{array}{c}\text { Atık } \\
(4-16) \\
(\mathrm{kg})\end{array}$} & \multirow[t]{2}{*}{$\begin{array}{c}\text { Doğal } \\
(16-32)(\mathrm{kg})\end{array}$} \\
\hline & & & & & & & & \\
\hline NRC & - & - & 62 & 300 & 185 & 639.252 & 578.547 & 577.663 \\
\hline SAC1 & 0.10 & 0.30 & 48 & 300 & 145 & 675.372 & 611.237 & 610.303 \\
\hline SAC2 & 0.15 & 0.45 & 48 & 300 & 145 & 675.372 & 611.237 & 610.303 \\
\hline SAC3 & 0.20 & 0.60 & 48 & 300 & 145 & 675.372 & 611.237 & 610.303 \\
\hline SAC4 & 0.25 & 0.75 & 48 & 300 & 145 & 675.372 & 611.237 & 610.303 \\
\hline SAC5 & 0.30 & 0.90 & 48 & 300 & 145 & 675.372 & 611.237 & 610.303 \\
\hline
\end{tabular}

Çalışmada, elek analizi TS 3530 EN 933-1 (1999), taze beton birim hacim ağırlık TS 2941 (1978), taze beton kıvam deneyi TS EN 12350-2 (2002), tek eksenli basınç dayanımı TS EN 12390-3 (2003), ultrases geçiş hızı ile ölçüm ASTM C 597 (2002)'ye göre yapılmıştır.

\section{Bulgular}

Doğal agrega, 0-4 mm (N1), 4-16 mm (N2) ve 16-32 mm (N3) olmak üzere üç gruba ayrılmıştır. A32-B32 sınır değerleri arasında bir granülometri değeri sağlamak için kendi aralarında \%30 N1, \%35 N2, \%35 N3 yüzdelerinde karıştırılmışlardır. Elde edilen karışıma ait granülometri eğrisi Şekil 1'de verilmiştir.

Atık betondan elde edilen agrega 4-8 mm (R1) ve 8-16 mm (R2) olmak üzere konkasörle kırılarak elde edildiğinden dolayı iki gruba ayrılmıştır. Atık beton agregasında uygun granülometriyi sağlayabilmek amacıyla doğal agregayla karıştırılmıştır. Karışım işlemi doğal agregayla yapılan karışımdaki 4-16 mm (N2) yerine, 4-16 $\mathrm{mm}$ atık beton agregası kullanılarak yapılmıştır. 4-16 mm atık beton agregası aralığında ise \%50 R1 ve \%50 R2 kullanılmıştır. Karışıma ait granülometri eğrisi Şekil 2'de verilmiştir. 


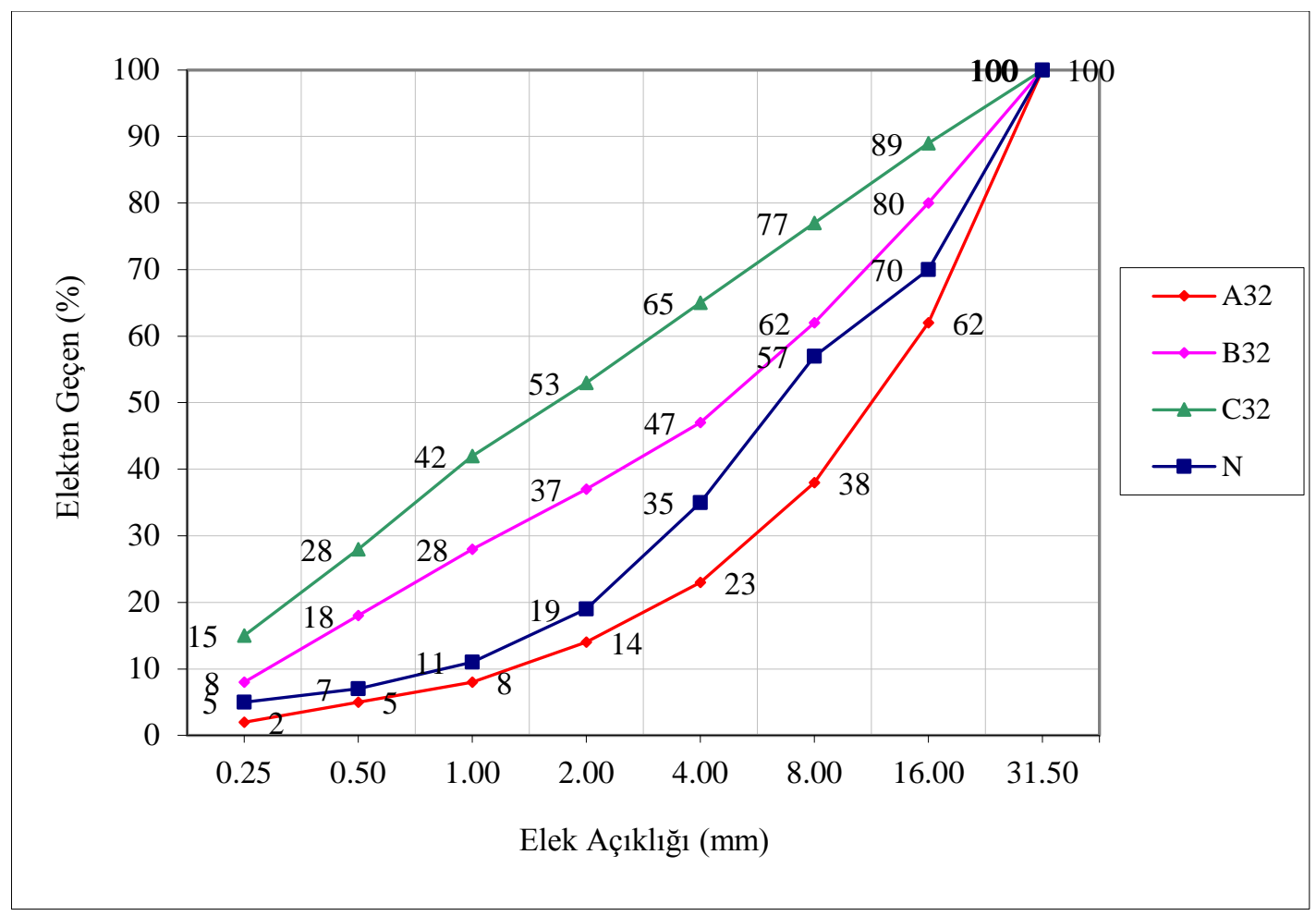

Şekil 1: Doğal agregaya ait granülometri eğrisi

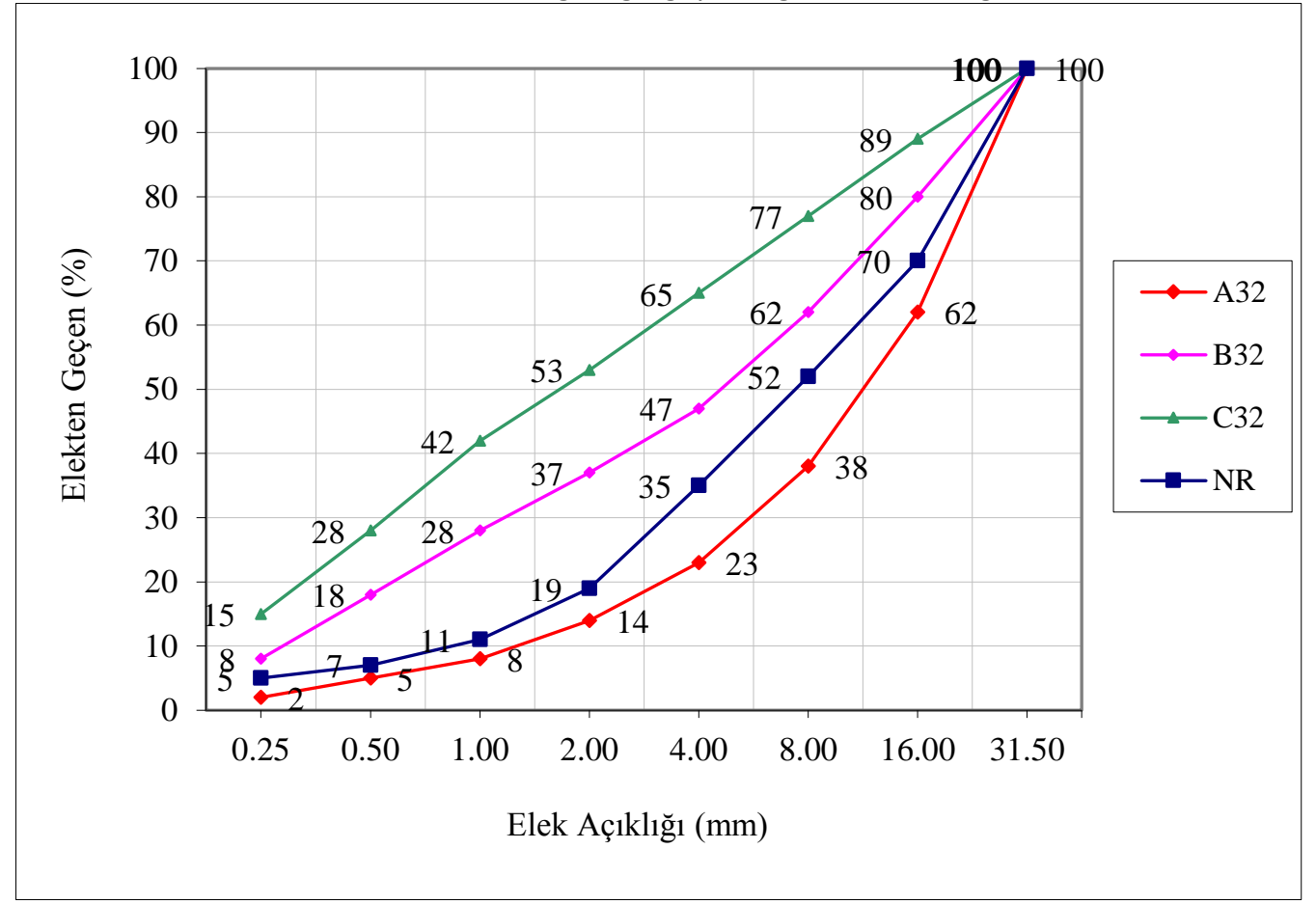

Şekil 2: Doğal ve atık beton agregasının karıştırılmasıyla elde edilen granülometri eğrisi

Yapılan deneysel çalışmalardan elde edilen sonuçlar tablo olarak Tablo 2' de, grafik halinde ise Şekil 3, 4, 5 ve 6 'da verilmiştir.

Süper akışkanlaştırıcı katkı kullanılan beton örneklerinde (SAC), karışım betonuna oranla birim hacim ağılık değerlerinde küçük fakat çökme değerlerinde \%22'ye varan bir artış gözlemlenmiştir. Birim hacim ağırlık değerlerinde, katkı miktarı arttıkça buna doğru orantılı olarak azda olsa bir artış gözlemlenmiştir. Yine aynı şekilde çökme değerlerinde katkı miktarının artmasına doğru orantılı olarak artış gözlemlenmiştir. Katkı kullanılan beton örneklerinde su miktarı azaltıldığından dolayı çökme değerleri yüksek artış göstermemiştir. 
Süper akışkanlaştırıcı ve yüksek oranda su azaltıcı özellik gösteren katkı kullanılan beton örneklerinde basınç dayanımının 7 günlük için \%23-36 ve 28 günlük için ise \%22-49 oranında arttığı görülmektedir. Tablo 2 incelendiğinde 7 ve 28 günlük dayanımların her ikisinde de en yüksek dayanım artışının \% 0.15 oranında katkı kullanılan SAC2 beton türünde olduğu belirlenmiştir. Dayanımlardaki yüksek orandaki artış, süper akışkanlaştırıcı katkının karışım suyu ihtiyacını azaltarak ve betonun daha iyi sıkışmasını sağlayarak, daha az boşluklu bir yapı oluşmasına katkı sağlamasıyla oluşmuştur.

Katkı kullanılan beton örneklerinde ultrases geçiş hızı değerlendirildiğinde, süper akışkanlaştırıcının ultrases geçiş hızını \%2.7-6 oranında arttırdığı belirlenmiştir. Ultrases değerlerindeki en yüksek artış SAC2 beton türünde görülmüştür. Süper akışkanlaştırıcı kullanılan betonlardaki ultrases geçiş hızı değerlerinin yükselmesi, süper akışkanlaştırıcı katkının betonun daha iyi sıkışmasını sağlayarak, daha az boşluklu bir yapı oluşturmasından kaynaklanmıştır.

Tablo 2: Birim hacim ağırlık, çökme, basınç dayanımı ve ultrases geçiş hızı deney sonuçları

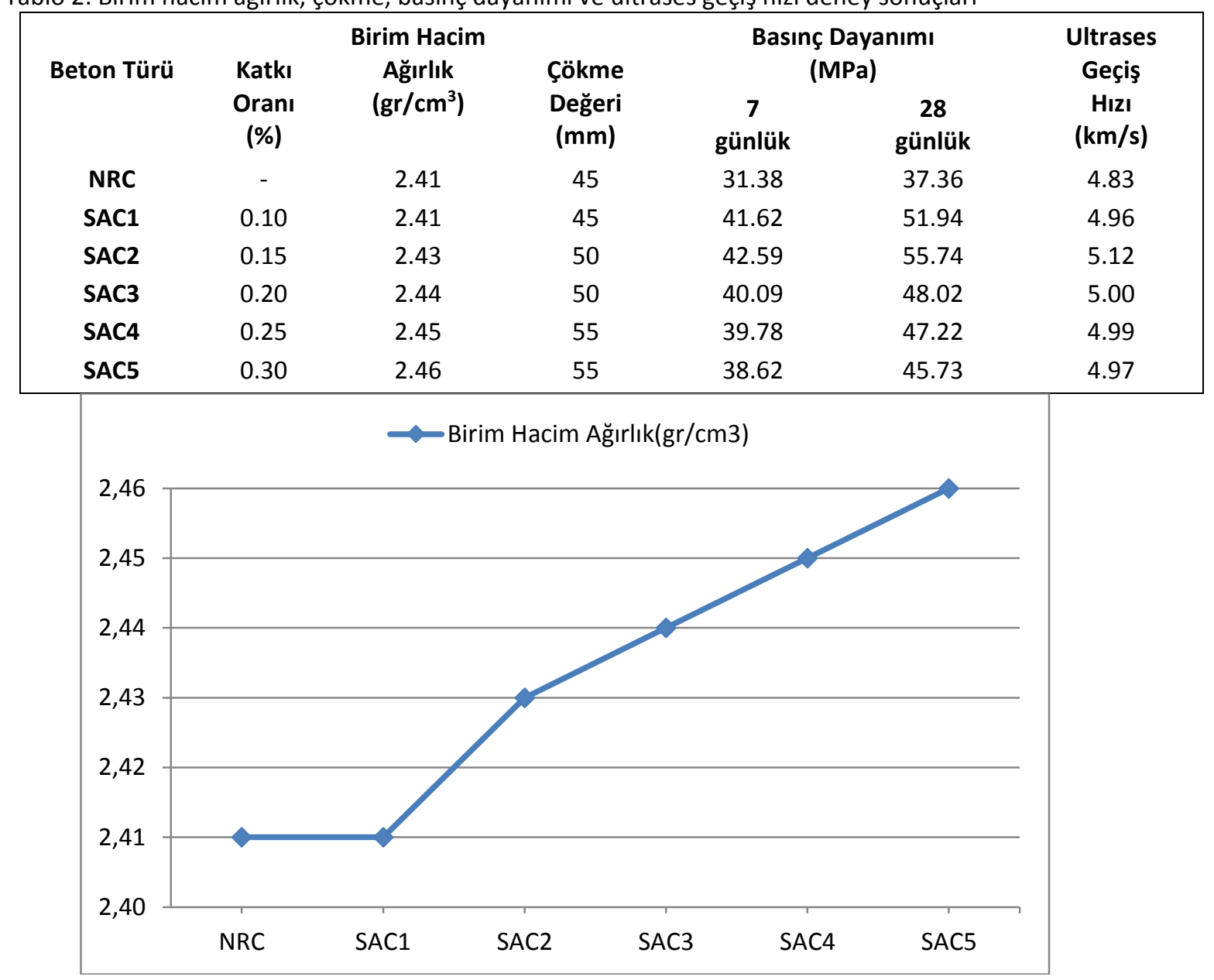

Şekil 3: Birim hacim ağırlık deneyi sonuç değerleri 

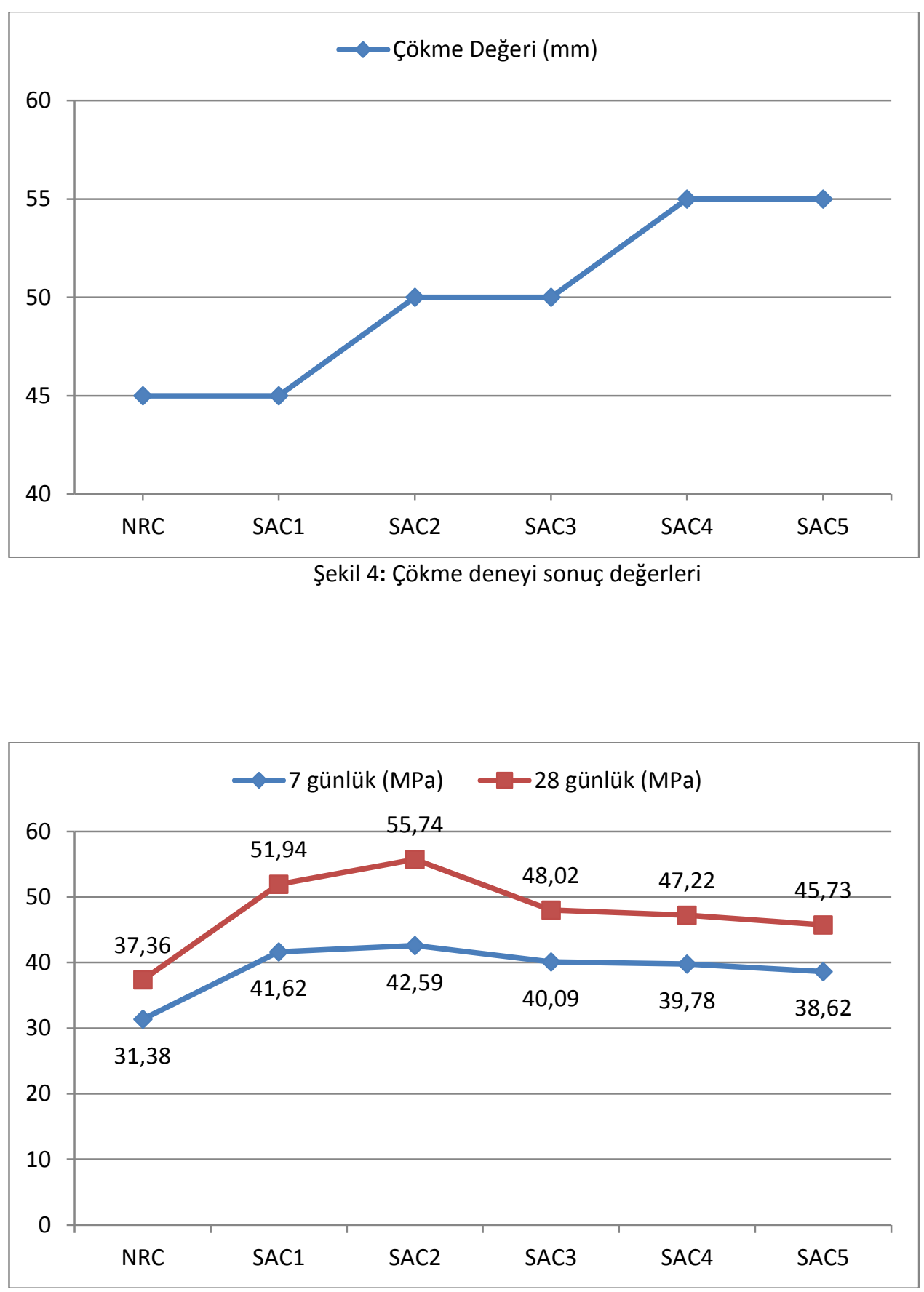

Şekil 5: Basınç dayanımı deneyi sonuç değerleri 


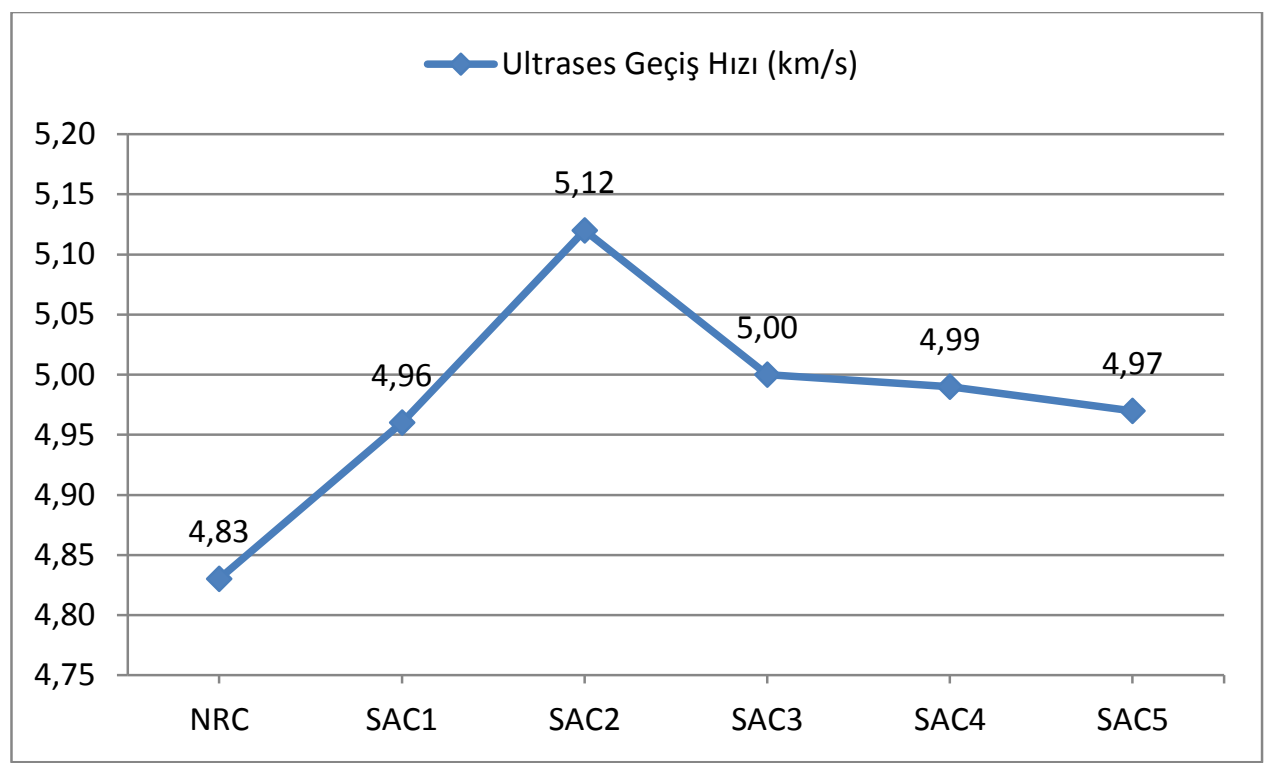

Şekil 6: Ultrases geçiş hızı sonuç değerleri

\section{Sonuçlar}

Bu çalışmada, atık betonlardan elde edilen agregaların taşıyıcı yapı elemanlarında kullanılabilirliği ve süper akışkanlaştırıcı katkıların, atık betonların geri dönüştürülmesiyle elde edilen betonlarda fiziksel ve mekanik özellikleri nasıl etkilediği araştırılmıştır.

Süper akışkanlaştırıcı ve yüksek oranda su azaltıcı özellik gösteren katkı kullanılan betonların, çökme değerlerinde \%22, basınç dayanımlarında \%22-49 ve ultrases geçiş hızlarında \%2.7-6 oranlarında artış olduğu görülmüştür. Özelliklede basınç dayanımını çok belirgin bir şekilde arttırdığı belirlenmiştir.

Atık beton agregalarının belirli oranlarda doğal agrega ile karıştırılarak ve katkı kullanılarak taşıyıcı yapı elemanlarında kullanılabileceği tespit edilmiştir.

\section{Öneriler}

Atık betonların geri dönüşümüyle elde edilen betonlarda yüksek dayanım elde edilmek isteniyorsa katkı olarak süper akışkanlaştırıcı ve yüksek oranda su azaltıcı özellik gösteren katkı kullanılmalıdır.

\section{Kaynakça}

Ajdukiewicz, A., Kliszczewicz, A., (2002). Influence of Recycled Concrete Aggregates on Properties of HS/HPC, Cement and Conc. Composites, V.24, p.269-279.

ASTM C 597, (2002). Standard Test Method for Pulse Velocity Through Concrete. Annual Book of ASTM Standards. Vol. 04.02. West Conshohocken, PA, 912 pp.

Buck, A.D., (1973). Recycled Concrete. Highway Research Record, No:930, Highway Research Board, p.8, England.

Erdin, E., Alten, A., Tunalı, T., (2004). İnşaat Atıklarının Değerlendirilmesi, 5. Endüstriyel Hammaddeler Sempozyumu, 13-14 Mayıs, İzmir, 387-393

Günçan, N.F., (1995). Eski Beton Kırığı Agregalı Betonların Fiziksel ve Mekanik Özellikleri, Yüksek Lisans Tezi, Osmangazi Üniversitesi Fen Bilimleri Enstitüsü, 44s, Eskişehir.

Hansen, T.C., Narud, H., (1983). Strength of Recycled Concrete Made from Crushed Concrete Coarse Aggregate, ACl, Concrete International, Design and Construction, vol.5, no.1, p.79-83, Germany.

Mukai, T., (1979). Study on Reuse of Waste Concrete for Aggregate of Concrete, Paper Presented at a Seminar on 'Energy and Resources Conservation in Concrete Tecnology', Japan-Us Cooperative Science Programme, San Francisco.

Mukai, T., Kikuchi, M., Koizumi, H., (1978). Fundamental Study on Bond Properties Between Recycled Aggregates Concrete and Steel Bars, Cement Association of Japan, Japan.

Nixon, P.J., (1978). Recycled Conrete as an Aggregate for Concrete, First State of Art Report RILEM TC-37-DRC, Materials and Structures (RILEM), no.65, p.371-378. 
Özsöylev, T., (1993). Hazır Beton ve Ekipmanları, Birsen Yayınevi, s.225, ìstanbul.

Postacıoğlu, B., (1975). Betonun Işslenebilme Özelliği. Yapı Malzemesi Problemleri, Çağlayan Kitabevi, 126 s., İstanbul.

Topçu, I.B., (1997). Physical and Mechanical Properties of Concretes Produced with Waste Concrete, Cement and Concrete Research, Vol:27, p.1817-1823.

Topçu, I.B., Şengel, S., (2004). Properties of Concretes Produced with Waste Concrete Aggregate, Cement and Concrete Research, Vol:34, p.1307-1312.

TS 2941, (1978). Taze Betonda Birim Hacim Ağırlık Tayini, Türk Standartları Enstitüsü, Ankara.

TS 3530 EN 933-1. Agrega Tane Büyüklüğü Dayanımı (Elek Analizi), Türk Standartları Enstitüsü, Ankara.

TS 802, (1985). Beton Karışım Hesap Esasları. Türk Standartları Enstitüsü, Ankara, $18 \mathrm{~s}$.

TS EN 12350-2. Taze Beton Kıvam Deneyi (Çökme Hunisi Metodu), Türk Standartları Enstitüsü, Ankara.

TS EN 12390-3. Numuneler Üzerinde Beton Basınç Deneyinin Yapılışı, Türk Standartları Enstitüsü, Ankara. 